\title{
Journal editor's note
}

This double issue of Bird Conservation International is a milestone volume in Neotropical bird migration studies that will stand independently on the shelves of many research biologists. We were very pleased to be asked, toward the end of 1993, to become the publication forum for these symposium proceedings, although this has naturally necessitated the journal taking the unusual step of publishing combined issues. There are no current plans to produce symposium volumes of this size on a regular basis, but the journal will continue to publish selected papers from BirdLife (and other important international) symposia. The journal has indeed already carried several papers presented at specialist group meetings in South America (on cracids, parrots) and several further contributions based on these meetings are expected.

This issue was prepared for typesetting at the start of 1994. I especially thank Regina Pfaff, who has loyally and expertly undertaken or managed all ICBP/ BirdLife's wordprocessing work for over to years, for her exceptional role in running checks and making extensive changes to bring the 13 typescripts into standard format. Martin Kelsey deserves many thanks for his considerable work in reviewing early drafts. Duncan Brooks and Colin Bibby advised me on specific points, and I also am most grateful to the authors and symposium editors, who were unfailingly cooperative in responding to many requests made at very short notice.

N. J. Collar 